Jessica Whyte

The Morals of the Market: Human Rights and the Rise of Neoliberalism London: Verso, 2019, 288 pp

\title{
Humans Rights Against Human Rights
}

NEIL VALLELLY

At a public meeting with supporters in February 2020, Act party leader David Seymour gave a speech titled 'Why Property Rights Matter'. ${ }^{1}$ It was a classic right-wing, libertarian, 'the government are coming to take all your things' kind of election-year speech. First, they come for your guns. Next, they're after your free speech. If you're not careful, they'll pilfer your small business. They'll even come for your racist jokes. And after you've been stripped of your guns, ability to exploit workers, and terrible sense of humour, they'll take all of your houses. Seymour couches his concerns about this apparently marauding and plundering government in the language of human rights: 'It's your right to the peaceful enjoyment of your property that this government doesn't get and happily violates'. At the same time, in subsequent interviews, Seymour is extremely critical of what he calls the 'left-wing manifesto' of the Human Rights Commission. ${ }^{2} \mathrm{He}$ is eager to remind his audience that current Human Rights Commissioner Paul Hunt ran (unsuccessfully) for a position on the National Policy Forum of Jeremy Corbyn's UK Labour party. On

1 David Seymour, 'Why property rights matter,' $A C T, 27$ February 2020.

2 Amelia Wade, 'Act's David Seymour calling for "hard-left" Human Rights Commission to be abolished,' NZ Herald, 29 October 2020. 
other occasions, he has described the Human Rights Commission as a 'hard-left organisation masquerading as a government department', noting that 'it has become irrelevant, even dangerous, when it cannot defend our most basic human right'. Of course, Seymour thinks this most basic human right is private property.

For Seymour, the Ihumātao protests and occupation symbolise everything that is wrong with contemporary human rights. In an interview on Magic FM, he claimed that 'at Ihumātao, Jacinda Ardern buckled under the pressure created by a tiny ragtag group of protestors. She took the side of people illegally occupying private property, rather than the owner of the property'. He went on to say something quite remarkable, yet unsurprising: 'I know there are those who will say, "oh, but the land was stolen in the $1850 \mathrm{~s}$ ". Well, yes, it was. Actually, many bad things happened in the 1850 s, [but] the simple question is this: do two wrongs make a right? If you think the solution to illegal land confiscation in 1850 is illegal land confiscation in 2020, I don't know how to talk to you'. ${ }^{3}$ Here, Seymour recasts the colonisation of Aotearoa as a legal private-property dispute, as if this concept and machinery of private property did not come along with the very process of colonisation itself.

Seymour's employment of human-rights discourse is two-fold. First, he situates private property as the foundational human right from which all other rights follow. He insists that 'the first and most important job of any government is to protect your rights to private property'. Gun-owners, freespeech defenders, small-business owners, employers, and landlords are the primary subjects of human rights in Seymour's world. Second, he uses the framework of private-property rights to argue that current human-rights institutions and legislation are inadequate to defend this fundamental right. So, on the one hand, the human right to private property must be defended at all costs; on the other hand, other human rights - namely, social and economic rights - must be denied if they endanger this foundational right to private property. In this sense, he uses human rights against human rights.

3 David Seymour, 'Government is the biggest threat to your private property,' Magic FM, 2 March 2020. 
On first glance, Seymour's appeal to human rights is at odds with how we usually encounter the discourse of human rights today. In the main, contemporary appeals to human rights tend to focus on violations of human dignity and liberty, experienced primarily by minority groups, with a specific focus on refugees and asylum seekers. Organisations like Amnesty International and Human Rights Watch regularly advocate on behalf of these groups and investigate breaches of human-rights legislation around the globe. But, as Jessica Whyte illustrates in her exceptional book, The Morals of the Market, property rights have rarely, if ever, been threatened by human-rights organisations and legislation over the neoliberal decades. Indeed, Seymour's argument is hardly new: he merely echoes the words of the Chicago School neoliberal and public intellectual Milton Friedman, who suggested that 'property rights are not in conflict with human rights. On the contrary, they are themselves the most basic of human rights and an essential foundation for other human rights. ${ }^{4}$

The difference between Seymour and the neoliberal thinkers of the $20^{\text {th }}$ century is not one of content but context. When the neoliberals pinpointed the threat of human-rights discourse to the foundational right to private property in the mid- $20^{\text {th }}$ century, they did so in the shadow of the atrocities of the Second World War and the signing of the United Nations Declaration of Human Rights in 1948. Further, the strength of post-war social democracy and the establishment of redistributive welfare states meant that social and economic rights, the right to housing, education, healthcare, and adequate living standards, for example, were on the table alongside the more traditional forms of civil and political rights, the right to private property, free speech, and equal protection under the law. The early neoliberals were also obsessively fearful about the post-war wave of decolonisation and the threat it posed to 'Western civilisation', especially with the rise of global redistributive proposals and postcolonial demands for control over national resources embodied in the (eventually failed) New International Economic Order. The neoliberals thus waged an ideological

4 Milton Friedman and Rose Friedman, Two Lucky People: Memoirs (Chicago: University of Chicago Press, 1998), 605. 
battle over what kinds of human rights would emerge as central to the global world order in the late- $20^{\text {th }}$ century. They began to win this battle in 1973, with Augusto Pinochet's violent overthrow of Salvador Allende's democratically elected socialist government in Chile.

Today, as David Harvey writes, we live 'in a world in which the rights of private property and the profit rate trump all other notions of rights'. ${ }^{5}$ This world exists because of the ideological battle fought by the neoliberals in the mid- to late- $20^{\text {th }}$ century. Another world was possible, where the right to housing, healthcare, education, and the like were prioritised over that of private property. This side of the battle was fought by newly postcolonial states, aware that, without a shift in the focus of rights, the old colonial power structures would only re-emerge in the neocolonial practices of global trade and the international division of labour. They were correct, but they still lost. Today, Seymour simply reaps the rewards of a battle that was won almost 50 years ago.

The Morals of the Market is an incisive, rigorous, and provocative history of the simultaneous rise of human rights and neoliberalism in the $20^{\text {th }}$ century. It seems to mark a shift in Whyte's trajectory away from continental political philosophy and towards intellectual history, albeit with a distinctly political bent. But there are some clear continuities with her first book, Catastrophe and Redemption. There, she analysed Giorgio Agamben's often vitriolic critique of human rights, focusing on his notion of 'bare life', 'a life that is politicised through the fact of its exclusion'. ${ }^{6}$ It is often these lives - in the form of, for instance, asylum seekers, refugees, prisoners, the homeless - that are the subjects of human rights. But where Whyte finds value in Agamben's thought, she is also critical of his failure to understand 'catastrophe' as a specific effect of capitalism. In many ways,

5 David Harvey, 'The Right to the City,' New Left Review 53 (2008): 23.

6 Jessica Whyte, Catastrophe and Redemption: The Political Thought of Giorgio Agamben (New York: SUNY Press, 2013). 
The Morals of the Markets provides the kind of critical account of capitalism missing in Agamben's work. Whyte shows us in meticulous detail that, if we are truly to understand how human rights operate today in an era of increasing human-rights crises, we must first examine how they came to exist alongside, and in collaboration with, neoliberalism. The result is a paradigm-shifting book, which not only changes how we think about human rights, but also how we conceive of neoliberalism itself.

Whyte sets out to understand why human-rights movements exploded at precisely the same time as neoliberalism switched from being a relatively marginal intellectual discourse to the dominant political, economic, and governance model across the global North and beyond. In doing so, Whyte enters into the burgeoning debate on the extent to which human-rights movements engaged with neoliberal ideas, or even collaborated with neoliberal governments and institutions, in the second half of the $20^{\text {th }}$ century. The best way to understand this debate is to examine how different critics of neoliberalism have interpreted human rights and neoliberalism in the context of Pinochet's military dictatorship in Chile. The most pertinent and divergent interpretations of these events come from the critical journalist Naomi Klein and the historian of human rights Samuel Moyn.

The brutal Pinochet regime-which prominent neoliberals such as Hayek, Friedman, and various Chicago School economists enthusiastically embraced and with which they collaborated-is associated with systematic human-rights violations as a result of the work done on the ground in Chile by human-rights NGOs. ${ }^{7}$ But as Whyte shows, 'the neoliberals in Chile mobilised a stark dichotomy between politics as violent, coercive and conflictual, and market relations as peaceful, voluntary and mutually beneficial'. ${ }^{8}$ The neoliberals were able to argue that the undeterred violence of Pinochet's regime was necessary to protect the pacifying nature of the market order. This order was to be protected from political interference

7 For more on the Chicago School influence in Chile, see Juan Gabriel Valdés, Pinochet's Economists: The Chicago School in Chile (Cambridge: Cambridge University Press, 1995).

8 Jessica Whyte, The Morals of the Market: Human Rights and the Rise of Neoliberalism (London: Verso, 2019), 160. 
at all costs, especially from those who threatened the sanctity of private property and called for redistributive economic policies. It is for this reason that both Friedman and Hayek described Pinochet's regime as a 'miracle'.

In her seminal history of neoliberalism, The Shock Doctrine, Klein argues that the economic shock treatment administered to the Chilean economy, designed and engineered by Friedman and the Chicago School 'boys', was, in the popular imagination, always distinct from the literal shock treatment that occurred in the torture chambers of Pinochet's regime. This separation is exemplified, Klein argues, by the fact that Friedman was awarded the Nobel Prize in Economics in 1976 (partly for his influence on the new Chilean economy), while Amnesty International won the Nobel Peace Prize in 1977 (for their reporting on abuses such as those in Chile). ${ }^{10}$ Against this separation, Klein suggests that the two forms of shock treatment were symbiotic, but that human-rights NGOs in Chile divorced the terror of Pinochet's regime from the political and economic reasons for its existence. 'By focusing purely on the crimes and not on the reasons behind them', writes Klein, 'the human rights movement . . . helped the Chicago School ideology to escape from its first bloody laboratory virtually unscathed'. ${ }^{11}$ This political blind-spot was built into the structure of Amnesty because of its commitment to impartiality. 'Amnesty's position', Klein claims, 'was that since human rights violations were a universal evil, wrong in and of themselves, it was not necessary to determine why abuses were taking place but to document them as meticulously and credibly as possible'. In the case of Pinochet's Chile, the desire to stamp out socialism and reshape the Chilean economy along neoliberal lines was a precondition for the violence of the regime. By focusing only on the physical violence, Klein suggests, organisations like Amnesty International turned a blind eye to the economic and political violence required to construct the new Chilean economy.

9 Quoted in Whyte, The Morals of the Market, 171.

10 Naomi Klein, The Shock Doctrine: The Rise of Disaster Capitalism (New York: Henry Holt, 2007), 117-118.

11 Klein, Shock Doctrine, 118. 
Samuel Moyn, a historian of human rights, dismisses Klein's argument as 'exaggerated and implausible'. ${ }^{12}$ He does not deny that neoliberalism and human rights share the same commitment to individualism, nor that human-rights movements did little to stem the march of neoliberalisation in the late- $20^{\text {th }}$ century. But he challenges the idea that the human-rights movement aided and abetted neoliberalism in the way that Klein suggests. For one thing, neoliberalism developed in different ways and at different times across the globe, whereas human-rights movements have remained relatively consistent in their activities and demands. Further, Moyn claims, despite the rampant inequalities of neoliberal capitalism, on some occasions neoliberalism has done more than human-rights movements to improve the social and economic conditions of some groups around the world by lifting them out of poverty. Against Klein, he characterises human-rights movements as 'powerless companions' of neoliberalism rather than active collaborators. ${ }^{13}$ This powerlessness, Moyn argues, has less to do with ascendant neoliberalism and more to do with the collapse of socialism and the decline of the left more generally in the late- $20^{\text {th }}$ century. It was this collapse that robbed the human-rights movement of a critical lexicon and political infrastructure for pursuing social and economic equality. 'It was not the job of human rights activists to save Marxism from its theoretical quandaries or the Left from its practical failures', insists Moyn. ${ }^{14}$ Instead, human-rights movements spoke the language of political and civil rights because this was the only language that could be heard.

Whyte is equally critical of Klein's argument, but for different reasons. Like Klein, Whyte criticises the role of human-rights movements in Chile, and beyond, in separating political violence from economic transformations. But rather than merely providing a screen that obfuscated the neoliberalisation of economies like Chile's, as Klein suggests, the focus on political violence over economic transformations 'bolstered the

12 Samuel, Moyn, Not Enough: Human Rights in an Unequal World (Cambridge, MA: Harvard University Press, 2018), 175.

13 Moyn, Not Enough, 176.

14 Moyn, Not Enough, 175. 
neoliberal dichotomy between violent politics and free civil society, thus contributing to a narrowing of the political and economic margins'. ${ }^{15}$ In other words, human-rights movements cemented neoliberal dreams of depoliticisation, which aimed to shield the market order from the threat of mass democracy. 'Amnesty's portrayal of politics as a field of "tension" and "polarisation", Whyte argues, 'reinforced the neoliberal attempt to constrain politics within strictly defined bounds, shaping a distinctly non-socialist future'. ${ }^{16}$ In this respect, contra Moyn, Whyte sees human rights not as 'powerless companions' but as 'fellow travellers' with neoliberalism, with both promoting the idea that politics is antithetical to human freedom. This vision lays the groundwork for neoliberal policies aimed not only at depoliticising the economic sphere, but at economising the political sphere, with the market framed as a pacifier for the violent realm of politics. In making this argument, Whyte is closely aligned with Quinn Slobodian, who has detailed the 'activist vision of statecraft' mobilised by neoliberal thinkers and designed 'to push back against the incipient power of democratically elected masses and those special interests, including unions and cartels, who sought to obstruct the free movement of competition and the international division of labour' ${ }^{17}$ If politics itself is viewed as potentially antithetical to human rights, as the actions of humanrights movements over the neoliberal decades suggest, then neoliberals found in the language of human rights the perfect means of promoting the pacifying and stabilising effects of the market against the violence and unpredictability of democracy.

The Morals of the Market is the most comprehensive and persuasive study of the relationship between neoliberalism and human rights to date. It

15 Whyte, Morals of the Market, 181.

16 Whyte, Morals of the Market, 181.

17 Quinn Slobodian, Globalists: The End of Empire and the Birth of Neoliberalism (Massachusetts: Harvard University Press, 2018), 93. 
illustrates that the neoliberal thinkers of the $20^{\text {th }}$ century were ambivalent at best, opportunistic at worst, towards the concept of human rights. On the one hand, they feared in human rights, particularly in social and economic rights, the seeds of a potentially totalitarian paternalism that would stymie individual flourishing and freedom, and, more practically, prevent Western countries from pilfering the natural resources of postcolonial nations. On the other hand, they saw in human rights— particularly civil and legal rightsan effective and malleable discourse that could be used to reinforce the linchpins of the neoliberal global project: the defence of private property, the promotion of competition, and the extension of the international division of labour. 'The challenge for neoliberals', writes Whyte, 'was to overcome the egalitarianism of communal cultures and the assumption that basic welfare was a right, and to instil the morals of the market and a culture of individual rights'. ${ }^{18}$ The neoliberals effectively inhabited the language of human rights in a way that protected individuals from state intervention and pushed against an alternative human-rights discourse that prioritised collective interests. As Whyte puts it, neoliberal human rights were 'not the rights to food, clothing, housing, and education enshrined in the [United Nations Declaration of Human Rights], which sought to offer some protection from market forces. On the contrary, neoliberal "economic rights" sought to protect the market freedom of private capital'. ${ }^{19}$ Human-rights movements themselves were seemingly more than happy to facilitate this version of human rights, as they shared a similar antagonism towards politics.

Whyte's book is a provocative challenge to us all. It makes the reader wary of the ways in which we reflexively appeal to human rights as a means of critiquing and potentially overcoming contemporary social and economic problems. To what or whom exactly are we appealing when we use the language of human rights? In early 2020, the visiting UN special rapporteur on the right to housing, Leilani Farha, told us that the housing and homeless situation in Aotearoa New Zealand was 'not just a housing 
crisis, but a human rights crisis of significant proportions ${ }^{20}$ By using the language of human rights, Farha sought to elevate the crisis beyond the everyday language of the political. 'A human rights crisis requires a human rights response', she stated, which 'must recognize in national law that housing is a fundamental human right requiring legal protection'. This statement illustrates that at least social and economic rights are up for discussion right now, a point that Whyte also makes in her conclusion to The Morals of the Market. But the attempt to elevate the housing crisis to the level of human rights also points to the limitations of human-rights discourse, especially when public figures like Seymour are simultaneously arguing that the right to housing contravenes the fundamental right to private property.

It is one thing to label housing as a human-rights issues, and another to actually do something about it. There are innumerable other issues around the globe, from refugees and ethnic genocides to the treatment of prisoners and victims of police brutality, that have been labelled as human-rights issues but are only worsening by the day. Whyte puts it more bluntly: 'Despite their claim to work in the interests of all human beings, the strength of official human rights organisations and institutions is not necessarily an index of the state of humanity itself'. ${ }^{21}$ In an age where human-rights organisations and legislation are strong, but human-rights abuses are increasing, we should question whether the very concept of human rights is actually effective in protecting people from the ravages of global capitalism.

Capitalism is conspicuously absent from Farha's critique of the housing situation in Aotearoa New Zealand. The idea that a small class of people (overwhelmingly Pākehā) can buy and own multiple properties, while a growing number of people (overwhelmingly Māori and Pasifika) find themselves homeless or in overcrowded and substandard housing, does not seem to be an issue in the context of human rights. The right to adequate

20 Jamie Ensor and Vita Molyneux, 'New Zealand's housing problem "human rights crisis of significant proportions,"' Newshub, 19 February 2020.

21 Whyte, Morals of the Market, 236. 
housing does not necessarily include the right not to be exploited by landlords, nor does it exclude the right to own as many properties as one wishes. Neither does the appeal to human rights say anything about an outof-control property market.

Today, then, human rights are at a fork in the road. One road will continue to take us along the same route, where human rights are limited to ameliorating, at best, or facilitating, at worst, the increasing inequalities of global capitalism. We've seen examples of this road in recent weeks, where Pharmac has used the Human Rights Act to legitimise the cutting of funding for a specific children's-cancer medicine under the dictate that to provide funding for one kind of illness discriminates against people with other kinds of illness. ${ }^{22}$ This kind of 'equality' encapsulates the legacy of neoliberal views on human rights; as Whyte notes, 'the neoliberals ... celebrated equal right precisely for its role in perpetuating existing inequalities. . . They saw a stress on formal equality before the law as a means to prevent redistribution for the purpose of greater substantive or socioeconomic equality'. ${ }^{23}$ Current human-rights legislation, as exemplified in the Pharmac example, can be used to uphold the right to be treated equally as an individual, a civil and political right, while trampling over the right to healthcare, an economic and social right. The former are the kinds of human rights that Seymour wants us to believe are the only form of human rights.

The other road would be to repoliticise human rights by tying them to an anti-capitalist, collective, and sustainable vision of the future. In her conclusion to The Morals of the Market, Whyte argues that if we are to liberate human rights in a truly transformative way, we must detach them from neoliberalism. She is right, of course. But we might go a step further and ask whether human rights are compatible with any kind of capitalist society. In an essay rethinking the concept of neoliberalism itself, Kean Birch and Simon Springer note that by criticising neoliberalism,

22 Guyon Espiner, 'Pharmac likely to end blanket funding for kids' cancer drugs,' RNZ, 3 May 2021.

23 Whyte, Morals of the Market, 220. 
we leave significant space for ostensibly "good" versions of capitalism'. ${ }^{24}$ This is perhaps also a danger in calling only to detach human rights from neoliberalism. Neoliberalism might exacerbate the violence of capitalism in ways that precipitate the very need for human rights but that violence is inherent in capitalism itself. Current human-rights movements seem to hold an unflinching faith in the promise of good capitalisms, believing that we can all have our rights alongside the inequalities, exploitation, and plundering necessary for capitalism to maintain its existence. It is time human rights started travelling in the opposite direction.

24 Kean Birch and Simon Springer, 'Peak Neoliberalism? Revisiting and Rethinking the Concept of Neoliberalism,' Ephemera: Theory \& Politics in Organization 19, no. 3 (2019): 476. 